\title{
Death: A Challenge
}

Dr. Tasneem Anjum

Associate Professor and Head, Department of English, Pratibha Niketan College, Nanded-431601, Maharashtra, India. tasneemanjum1961@yahoo.com

\begin{abstract}
Death is a reality, and not a concept. The subject of death has intrigued poets and philosophers since times immemorial. The question is as old as life itself. But to take away one's own life before the ordained time has neither moral/legal sanction, nor the religious approval. It evokes mixed feelings of pity, fear and a wonder whether the person could have solved the problem in any other rational manner. Psychologists brand them as maniacs and say that they are not brave enough to face the life with all its problems. But to take 'Death' as a challenge and to have many encounters with it is something remarkable.
\end{abstract}

Keywords - Ambitious, Challenge, Death, Mourn Suicide.

They thought death was worth it, but I

Have a self to recover, a queen

Is she dead, is she sleeping?

Where has she been,

With her lion-red-body,

Her wings of glass.

\section{(Stings) Sylvia Plath}

Sylvia Plath, in her poems has sketched 'Death' in many colours without sounding morbid or cynical. She talks in a very casual tone, as if Death is another friend of hers and extends her hand of friendship. For her, dying is not a painful end, but an art.

Dying is an art, like everything else

I do it exceptionally well.

She confesses:

The first time it happened I was ten.

It was an accident.

The second time I meant

To last it out and not come back at all.

I rocked shut

As a sea-shell

They had to call and call

And pick the worms off me like sticky pearls

$$
\text { (Lady Lazarus) }
$$

She gives her reasons in the same poem

I do it so it feels like hell

I do it so it feels real.

I guess you could say I've a call.

It was a child's play for her, hence she repeated it

One in every ten as

It's easy enough to do it in a cell

It's easy enough to do it and stay put
What troubled her was not the ugly scar which death is likely to leave on her but the comments of the people

... the same brute

Amused shout:

A miracle:

That knows me out.

Plath's annoyance marks the conclusion of the poem. She swears on God and on her dead father:

Her God, Her Lucifer,

Be-ware

Beware.

Out of the ash

I rise with my red hair

And eat men like air.

The reasons for this wrath should be traced at two levels-biographical and poetical. Sylvia Plath, as a child, was introduced to 'Death' as experience in a rude practical way when she lost her father. Her mother did not wish that she should see the dead body. Aurelia writes about this in her introduction to the book Letters Home: When I viewed Otto at the funeral parlor, he bore no resemblance to the husband I knew, but looked like a fashionable store manikin. The children would never recognize their father, I felt, so I did not take them to the funeral ... what I intended as an exercise in courage for the sake of my children, was interpreted years later by my daughter as indifference. 'My mother never had time to mourn my father's death.' 
Plath's experiments with 'Death' began right at this stage. All her biographers mention about her first attempt to kill herself at the age of ten, but not much light has been thrown on the incident. It is conspicuously omitted by her mother too, where as the second attempt is described with all emotion. Plath herself mentions about it in her poem 'Lady Lazarus'.

'The first time it happened

I was ten'

Plath might have done it with childish inquisitiveness, or she might be too young to articulate the intensity behind the experience.

It was the second experience which intrigued the many critics. She was a bright, cheerful, ambitious girl and successful in every apparent way with good academic background. Her Letters Home gives ample evidence of her enthusiasm and excitement. She used to send her mother a poem instead of a letter or write to her brother how sunny as her life at smiths. Her mother leaves the readers to analyze it for themselves and tells how the incident took place:

Propped against a bowl of flowers on the diningroom table was a note in Sylvia's hand writing: 'Have gone for a long walk, will be home tomorrow.'

Grammy came from her room, distraught saying, 'We had no idea she was so ill, she should not have been left alone. Granny's crying. The night-mare of nightmares had begun.

The report of Sylvia's disappearance which I phoned to the police was issued over the radio. Then I discovered that the lock to my steel case had been broken open and the bottle of sleeping pills was missing. ${ }^{2}$

To continue the episode in Sylvia's language:

My brother finally heard my weak yells, called the ambulance, and the next days were a night mare of flashing lights, strange voices, large needles, an over powering conviction that is was blind in one eye and a hatred towards the people who would not let me die, but insisted rather in dragging me back into the hell of sordid and meaningless existence and hopes the worst was over. ${ }^{3}$

She was treated and nursed by good doctors and friends who enabled her to return to "Smith" for the second semester. "She picked up an active "date life," which helped build up confidence, and she said she enjoyed herself "in a casual, hedonistic way." 4
Plath has successfully fantasized this stage of her life in her novel The Bell Jar.

Her self-discipline and confidence were steadily developing. Her ambition to develop herself as a creative writer started paying dividends. She had felt "great advances in my poetry, the main one being a growing victory over word nuances and a superfluity of adjectives." 5

The two Fulbright years stand out as the most exciting and colorful events in Sylvia Plath's life. In a fairly short time, she adjusted to the multiple changes and challenges of the university environment in Cambridge. She reasoned that a life of "reading widely, talking deeply with all types of people and living fully" would give her the background necessary to enrich her creative writing. Two visits to the continent whetted her appetite for more travel.

In February, 1956 she found herself a "life partner" in Ted Hughes, a British poet, and got married to him at a secret wedding ceremony in the Church of St. George the Martyr, London on June $15^{\text {th }} 1956$. Of course, she had her mother's consent for this and she saw them off for "a writing honeymoon on a shoe string budget in Spain. They set up a house, had children, Frieda and Nick. She wrote prolifically at this stage in spite of her domestic obstacles and ill health. Sylvia wrote to her mother proudly, "I have everything in life I've wanted: a wonderful husband, two adorable children, a lovely home and my writing." 6

Plath's mother could sense a tension between the couple. The marriage was seriously troubled, and there was a great deal of anxiety in the air. Ted had been seeing someone else, and Sylvia's jealousy was justifiably very intense.

In the month of August, she announced her legal separation from Ted and lived separately with her children. She wrote to her mother that "I am enjoying my rather frustrating (culturally and humanly) exile now. I am doing a poem a morning, great things, and as soon as the nurse settles, shall try to do my second novel."7

Plath refused all helps from her mother, and wanted to show the world that she can lead an independent life. Her physical energies had been depleted by illness, anxiety and over-work, and although she had for so long managed to be gallant and equal to the lifeexperience, some darker day than usual had temporarily made it seem impossible to pursue.

She committed suicide on February 12, 1963.

Plath has her own reasons to offer at poetic level, regarding the same aspect "Death". She has used love, death and poetry- all these three terms as synonyms. 
The blood jet is poetry,

There is no stopping to it.

(Kindness)

The blood is the flood of love.

(The Munich Mannequins)

Many of her love poems echo "death" and poems with death as the central theme can be interpreted as love poems too. It can therefore, be said that she was in love with "death". She viewed death sometimes as an instrument to meet her dead father: sometimes to return to the womb with a hope of rebirth.

She believed: "And like the cat I have nine times to die" (Lady Lazarus).

Plath gets over the feeling of getting "back, back, back to you" after writing "Bee poems" and wanted to take revenge on the world.

Her God, Her Lucifer,

Beware

Beware

Out of the ash

I rise with my red hair

And I eat men like air.

\section{(Lady Lazarus)}

This "Phoenix" image haunts her bleak poetic universe which is full of "hooks", "moon" "coiled serpents" "black man" "old corpses" "haunting cats" "spider-men". She entered a "torture cell walled with family portraits." 8 Every painful incident of her life becomes poetry, a cut, a fever, a bruise, child-birth, hospitalization. Her attempt to achieve perfection fails and that "failure" glows in her poems.

In the poem "Fever $103^{0 "}$, she burns with rage to become "pure". "This poem is about two kinds of fire- the fires of hell, which merely agonize and the fires of heaven, which purify. During the poem, the first sort of fire suffers itself into the second." 9

Plath wanted to become pure

I am too pure for you or anyone

Your body

Hurts me as the world hurts God.

She wanted be the "Most pure":

Aura pure acetylene

Virgin

Attend by roses,

By kisses, by cherubim,
By whatever these pink things mean.

Not you, nor him

$\left(\right.$ Fever $\left.103^{0}\right)$

Sex becomes repulsive and other morbid things like 'cut' start exciting her. what a thrill-

My thumb instead of an onion. The top quite gone.

It appears like a "little pilgrim" and she enjoys the "thin papery feeling" and welcomes "Death" with "carpet rolls straight from the heart." (Cut) The "Death bell" tolls for her in the poem "Death and Co." she is now his (Death's) "red meat". His bleak claps side nix wearing and "Indian death-gown" she becomes frigid.

Earlier she had regretted the borrowing of the "stilts of an old tragedy" while writing "Electra on Azalea Plath". She sheds this attitude and brilliantly rides "Ariel" - a poem about her favorite horse.

And now I

Foam to wheat, a glitter of seas.

The child's cry

Melts in the wall

And I

Am the arrow,

The dew that flies

Suicidal, at one with the drive

In to the red

Eye, the cauldron of morning.

(Ariel)

Alvarez comments that the horse too was in an emotional state like the rider. "So finally the poem is not just about the Stallion "Ariel"; "it is about what happens when the 'Static in darkness' ceases to be static, when the potential violence of the animal is unleashed."10

In the poem "Edge"

... back into her body as petals

Of a rose close when the garden

Stiffens and odours bleed From the sweet, deep throats of the Night flower.

(Edge)

Critics find an allusion here to Shakespeare's Cleopatra, another perfectionist in the technique of dying, ${ }^{12}$ the fusion of the sexual and elegiac overtones in the image of 
the violently aborted life in the last line reveals a Baudelaire and subtlety.

The burning rage about "Death" is absent in Plath's later poems, as she feels only a shadow of hers exists. The fixed vortex becomes more powerful in her poems.

Fixed vortex on the far

Tip, riveting Stones, air,

All of it, together.

(Man in Balch)

There is a kind of stillness about the "Sea" of Plath's poems. She wanted her soul to be reflected in that.

They threaten

To let me through to a heaven

Stenless and fatherless, a dark water

\section{(Sheep in fog)}

In her essay "Ocean-1212" she draws a vivid picture. She says: "Mountains terrify me - they just sit about, they are so proud. The stillness of hills stifles me like fat pillows. When I was not walking along side the sea, I was on it or in it."11

Many of critics agree that was the stage in her life where there was no difference between the real sea and imaginary sea. Her mind and the world, her sea and the real sea did not divide until she was nine. She learned to grow out of her child hood sentiments and viewed at it more objectively.

Sometimes the Death wish is expressed in a strikingly simple language. When Plath says:

I am Vertical

But I would rather be horizontal

(I am vertical)

In the poem "Cut" a simple domestic imagery is related to historical facts. It is well exploited to bring about the historical allegory. The blood coming out of the cut thumb becomes a red, soft, satin like carpet. The sight of his blood raises curtain and in quick succession the acts of violence and bloodshed which forms the history of America appear one by one on the mind stage of the poet. The thumb becomes "little Pilgrim". The puritans, who migrated from England, came to America and ousted the native red Indians from their legitimate country. With its top cut the thumb becomes a headless body of the founding father, the head having been axed by the red Indians.
Scores of memoirs appeared in the short span of time and the critical works being added to that, speaks for them. It is the self imposed restraint, both in her life and in poetry as well, leads to despair. 'The wonderful years of her life with Ted' which she writes and tells her mother, could not find place in any of her poems. This camouflage forces her to lead a double role in life, psychologically, a split personality. In art, this can lead to silence but in life to suicide. She comes to a stage where death and birth mean one and the same. She wanted to go back to the womb in exposition of "lost-self". This strain runs throughout her poems and gives a feeling that she might have died to give authenticity to her poetry.

\section{REFERENCES}

[1] Aurelia Schober Plath, Letter Home (New York, 1975), p. 25.

[2] Ibid., p.125.

[3] Ibid., p. 132.

[4] Ibid., p. 134.

[5] Ibid., p. 157.

[6] Ibid., p.438.

[7] Ibid., p. 537.

[8] Charles Newman, The Art of Sylvia Plath (London, 1973), p. 187.

[9] Gary Lane, Sylvia Plath, New Views on the Poetry (London, 1979), p. 203.

[10] A. Alvarez, Sylvia Plath (London, 1973), p.58. Quoted from the collection of Charles Newman.

[11] Charles Newman, The Art of Sylvia Plath (London, 1973), p.187. 